\title{
BUDDHISM IN THE POETIC WORKS OF INNOKENTY ANNENSKY
}

\author{
Aleksandr A. Shuneyko \\ Komsomolsk-on-Amur State University, Komsomolsk-on-Amur, Russia \\ Olga V. Chibisova \\ Komsomolsk-on-Amur State University, Komsomolsk-on-Amur, Russia
}

\begin{abstract}
The importance of the work is determined by the place which I. Annensky occupies in Russian poetry and his unrelenting influence on generations of readers. The purpose of the work is to reveal the presence and linguistic ways of implementing the semantics of the Buddhist understanding of the world in the poetic heritage of I. Annensky. The material for the study is all original poems of the poet. The main methods are semantic, comparative and intertextual analysis. From the days of his study at the university, the poet was well acquainted with the basics of Buddhism and demonstrated obsession with it throughout his life. Several poems undoubtedly present semantic complexes that are directly referred to Buddhism, refurbishing its major provisions. The ways of translating Buddhist semantics are diverse and they are always organically interwoven into an artistic whole. The language of the poet is consistently focused on ambiguity, uncertainty and ambivalence, which is manifested at various text levels. The work lists the main language transformations used by the poet. It is illustrated on the example of the poem " $\infty$ ", which mysteriousness steadily draws the attention of readers and researchers. The author shows that the poem realizes the Buddhist conception of the ratio of extremely small and infinitely large quantities, implying their identity. The authors draw a parallel between the lines of I. Annensky and W. Blake which implement identical Buddhist ideas. The conclusion outlines the prospects for a detailed analysis of other texts.

Key words: poetic text, linguapoetics, Innokenty Annensky, Buddhism, semantics of Buddhism, semantics of infinity and instant, language transformations.
\end{abstract}

Citation. Shuneyko A.A., Chibisova O.V. Buddhism in the Poetic Works of Innokenty Annensky. Vestnik Volgogradskogo gosudarstvennogo universiteta. Seriya 2, Yazykoznanie [Science Journal of Volgograd State University. Linguistics], 2019, vol. 18, no. 1, pp. 180-186. DOI: https://doi.org/10.15688/jvolsu2.2019.1.15

\section{БУДДИЗМ В ПОЭТИЧЕСКОМ ТВОРЧЕСТВЕ ИННОКЕНТИЯ АННЕНСКОГО}

\section{Александр Альфредович Шунейко}

Комсомольский-на-Амуре государственный университет, г. Комсомольск-на-Амуре, Россия

\section{Ольга Владимировна Чибисова}

Комсомольский-на-Амуре государственный университет, г. Комсомольск-на-Амуре, Россия

Аннотация. Актуальность исследования обусловлена значимостью творчества Иннокентия Анненского для русской поэзии и его неослабевающим влиянием на поколения читателей. Показано, что отличительной чертой поэтического наследия И. Анненского является его связь с семантикой буддизма. Цель работывыявить способы воплощения в языке поэта особенностей буддийского понимания мира. Материалом для изучения послужили все оригинальные стихотворения И. Анненского. Исследование проведено с применением методов семантического, сопоставительного и интертекстуального анализа. Выявлены стихотворные произведения, содержащие семантические комплексы, прямо отсылающие к философии и ритуалам буддиз- 
ма. Охарактеризованы разнообразные способы трансляции буддийской семантики и показана их обусловленность последовательной ориентированностью И. Анненского на неоднозначность, неопределенность и амбивалентность, которые проявляются на различных текстовых уровнях. Описаны основные языковые преобразования, осуществленные поэтом для выражения семантики буддизма. Проведена параллель между строчками И. Анненского и английского поэта У. Блейка, в которых нашли отражение одни и те же буддийские представления. Намечены перспективы исследования семантики буддизма и способов ее выражения в других оригинальных текстах И. Анненского - критических статьях и драматических произведениях.

Ключевые слова: поэтический текст, лингвопоэтика, Иннокентий Анненский, буддизм, семантика буддизма, семантика бесконечности и мгновенности, языковые трансформации.

Цитирование. Шунейко А. А., Чибисова О. В. Буддизм в поэтическом творчестве Иннокентия Анненского // Вестник Волгоградского государственного университета. Серия 2, Языкознание. - 2019. - Т. 18, № 1. C. 180-186. -(На англ.). - DOI: https://doi.org/10.15688/jvolsu2.2019.1.15

\section{Introduction}

The Russian tradition of studieson a poetic language and style is burdened with a strange rule: in the creative works of domestic poets it is almost obligatory to look for lexemes and whole semantic complexes directly related to Christianity. Now they are being hunted with the same effort and found with the same success as the features of outspoken atheism were discovered twenty years ago. At that, it is tacitly assumed that the bigger a poet is, the more he is concentrated on Christianity, the more of its motives he displays.

Meanwhile, the opposite is obvious: the bigger a poet is, the more universally he accumulates the world experience, the more units referring to all sorts of traditions he includes in his language.

It seems particularly helpless to limit to Christian ideas those artists who openly declared their ideological attitudes which were far from being Christian. These included I. Annensky, who, with the character of his linguistic, exploratory and aesthetic quest, was clearly oriented towards pre-Christian value systems and language pictures of the world. His artistic discoveries were determined by the pursuit of ancient ideals and comprehension of the constants of the Buddhist worldview.

The assimilation of Buddhism through literary forms periodically falls into the researchers' field of view. Examples include the researches of A. Di Ruocco [Ruocco, 2011], A.A. Shuneyko [Shuneyko, 2016] and R.F. Bekmetov [Bekmetov, 2015]. They discuss the historical and literary aspects of the Buddhist theme and emphasize the value of the era, the atmosphere of which was filled with interest in the East because of the crisis of official Orthodoxy.

\section{Extralinguistic factors of confirmation}

The close and nonrandom connection between I. Annensky and Buddhism has a number of direct and indirect confirmations. They need to be listed, because they are the extralinguistic factors that confirm the authors' observations.

According to B.V. Varneke, I. Annensky used to call I.P. Minaev, a university professor, his teacher, of whom "he constantly responded with special reverence" [Varneke, 1910, p. 38]. I.P. Minaev was a Sanskritologist, an Indologist and one of the lead researchers of Buddhism in Russia. He translated and published Buddhist manuscripts, issued several works that laid the foundation for national Buddhist studies. It was from this person that I. Annensky received deep knowledge about Buddhism, got interested in it, and judging by the peculiarities of poet's creative realizations it stayed active throughout his life.

The poem of I. Annensky "Buddhist Mass in Paris" has repeatedly attracted the attention of researchers [Dugarov, 2016; Ruocco, 2011]. It is a direct evidence that both eight years after the death of the teacher (that is, in 1898, when the poet was present at the divine service at the Guimet Museum), and sixteen years after it (that is, in 1906, when he published his first text in the collection "Northern Speech") Annensky's interest in Buddhism was not dispelled, and its perception remained full of reverential admiration, bordering on exalted veneration. That is, throughout his life, beginning with the university bench, I. Annensky remained an enthusiastic partaker of Buddhist doctrines, a man who correlated them with his own destiny, the nature of his worldview and creativity is embodied in his language one way or another. 


\section{МАТЕРИАЛЫ И СООБЩЕНИЯ}

Annensky's character of self-consciousness was far from the Christian but close to the Buddhist one, which is clearly seen in his poetry. S. Makovsky pointed to the motives of 'egotism' and 'hypnotism', that are revealed with contemplation of the inner world, desire to stay in a personal shell and contemplate the beauty of the word, inspire personal images that arise of the truth of moral demands [Makovsky, 1955, p. 249].

In his critical texts I. Annensky repeatedly formulates the settings that duplicate the Buddhist maxims and that are their actual paraphrases. For example, a constant that assumes the identity of the personal principle and the world (everything in me and I am in everything) is formulated as follows: "... I, which eagerly seek to absorb this world and become it, making it myself ..." [Annensky, 1979, p. 206]; “... I, which would like to become an entire world, dissolve, spread in it ..." [Annensky, 1979, p. 102].

\section{Linguistic features of the embodiment}

The semantic analysis shows that many poems by I. Annensky are directly associated with Buddhism. On the language level, the semantic complexes associated with Buddhism find their embodiment in a number of aesthetically justified language transformations and a specific selection of linguistic means. Below the main ones are listed.

The combination of different tropes results in saturating a particular segment of the text with various mutually intercompatible meanings. For example, in the poem " $\infty$ " the following tropes are used: Its promises come true in dials / In circles of enamel minutes ( $\mathrm{V}$ krugu emalevykh minut / Yeyo svershayutsya obety). "Circles of minutes" (Krug minut) is a metonymy, "enamel minutes" (emalevyye minuty) is a metaphor, "promises come true" (svershayutsya obety) is a personification. Thus, a single detailed periphrastic description, itself being a transformation, may include three more independent transformations (metaphor, metonymy and personification) that are merged into a single complex, dispersing meanings and collecting them at one point.

A word might have several simultaneously updated meanings. In the poem "Impossible" (Nevozmozhno) the word placed in the title is characterized both as sad and tender: "But among them there's nothing more dismal / Or gentle than you <... >" (No mezh nikh ni pechal'neye net, / Ni nezhneye tebya $<\ldots>$ ). That is, various lexical and connotative meanings are actualized, their combinations generate the effect of uncertainty. Similar transformations are carried out at the grammatical level. For example, in the poem "Moonlit Night at the End of Winter" (Lunnaya noch' na iskhode zimy) the second line implies two equal concepts concurrently: "We are forgotten at night $<\ldots>$ and We are forgotten by the night <... ".

The ambivalence of lexical, associative and text semantics manifests itself repeatedly. For example, in the poem "The old barrel organ" (Staraya sharmanka) the old barrel organ itself and the shaft rotating inside it are a designation of poetic creativity, of the poet himself. At the same time creativity is perceived simultaneously as torment, necessity, inevitability and joy. Such a wide range of associative and nominative meanings generates a special effect of the depth in the poetic text. Ambivalence is based on the real or potential enantiosemy of the linguistic units used by the author.

The ambiguity of the author's assessment is often conjugated with weak semantic positions of lexical and some other text units. For example, in the poem "Drowsiness" (Dremotnost') the general context of the description does not help in determining within the text the kind of cold (environment or relations) injures of the poet. Parallelism between personal experiences and the state of nature, their amalgamation into a single whole creates a high level of poetic uncertainty.

The diffusion of the boundaries between synonyms and contextual synonymy lead, in principle, to the result of marking the depicted world as mixed. For example, in the poem "Moonlit Night at the End of Winter" (Lunnaya noch' na iskhode zimy) the space is defined simultaneously as a flag station and a forest glade.

\section{Realization of the semantic complexes of Buddhism}

With due account taken of these linguistic features, further is considered the realization of the semantic complexes of Buddhism in I. Annensky's poem for the name of which the poet chose the sign of infinity " $\infty$ ". This poem, undated in the author's autograph, was published 
second in "The Quiet songs" (Tikhiye pesni) collection of 1904. It should be noted that there are very few translations of Annensky into English. One explanation can be the idea of H.M. Catriona [Catriona, 1985, p. 308]: "At first sight his poetry appears as a series of fragmentary, disconnected or even contradictory utterances, which, though they contain few obscure or even unusual words, are yet stylistically baffling". The other is expressed by D.W. McDuff, who considers that I. Annensky felt " a desire to imbue the poetic word with as many meanings as possible" [McDuff, 1970, p. 39]. Howbeit, those translations that exist often do not preserve the rhythmic and prosodic structure of the text, thus depriving the reader of opportunities to touch its formal features. That is why the authors take the liberty to suggest their variant of translation.

\author{
Девиз Таинственной похож \\ На опрокинутое 8: \\ Она - отраднейшая ложь \\ Из всех, что мы в сознанье носим. \\ Device of Mystery is like \\ The number eight resupinated. \\ It is a highly welcome lie \\ Persisting in the minds of mankind. \\ В кругу эмалевых минут \\ Ее свершаются обеты, \\ А в сумрак звездами блеснут \\ Иль ветром полночи пропеты. \\ Its promises come true in dials \\ In circles of enamel minutes, \\ At twilight they effulge as stars \\ Or else are sung by wind of midnight. \\ Но где светил погасших лик \\ Остановил для нас теченье, \\ Там Бесконечность - только миг, \\ Дробимый молнией мученья. \\ But where the extinguished suns \\ Prevented us from moving forward, \\ Infinity becomes a blink \\ Split by the lightning of a torment.
}

The conceptual composition of this text is structured with two statements, which are contradictory on the logical level: Infinity is a lie and Infinity is a moment. If Infinity is a lie that is it does not exist, there is no point in talking about its substantive, essential or any other characteristics. The author not only does it, but affirms the properties with temperament and power of the prophet who has grasped the truth and who is expending a huge amount of emotional energy in order to make his knowledge the property of all.

This contradiction is potentially gently resolved by three methods or assumptions. 1 . The lie is not Infinity itself, but only its widespread external designation in the form of a mathematical sign. 2. The lie is not Infinity itself, but only a concept of it, fixed in human consciousness. 3. Infinity is a lie only on the material plane. If it is perceived outside the tangible world, leaving its boundaries one way or another, it immediately acquires its true full multidimensional existence. The poem contains explicit impulses and confirmations for every of three versions. "Device of Mystery" is a name, a sign of Infinity. "Persisting in the minds of mankind" states that one of the places where Infinity exists is our consciousness. "In circles of enamel minutes" means within the boundaries of the clock that is within the material plan. And at the same time, the components of the text do not exactly allow any of them to be preferred. In their integrity they become even more convincing.

This dynamic alogism, throbbing on the verge of resolution but never receiving it, attracts the reader's attention and actualizes perceptive mechanisms, creates a cognitive dissonance. Regardless of the way to neutralize the contradiction, its second part "Infinity is a moment" remains always veritable. This, in its turn, strengthens the weight of its emotional impact: among the vaguely flickering assumptions, there is one truth.

What does this line mean? How can it be meaningfully interpreted? What spiritual or worldview maxim stands up for it? The authors attempt to outline the answers to these questions.

The statement can be understood as the sum of the experience received by the poet on the material plane. A rather curious generalization, it states that, when being alone, the poet might condemn himself to the torture of the theomachy denial and the ghost of death, which he expected every minute without believing in the other world and tormented by his unbelief' [Makovsky, 1955, p. 225]. Unchanged in the obsessive horror of everyday life, the state of the poet's soul could well be projected in his mind into such a generalization that summarizes the sorrowful outcome of the current life. 
The maxim of spiritual experience is always included in a worldview model, thus representing more general ideas. There is an attempt to interpret the poem through the coordinate system of V. Solovyov [Borovskaya, 2009]. There is an attempt to ascribe Christian mysticism to I. Annensky [Nalagach, 2003]. Nevertheless, these attempts are contrary, firstly, to the above considerations. Secondly, they do not correlate with the opinion of S. Makovsky, who had claimed having a conversation on a religious topic with Vyacheslav Ivanov and Innokenty Annensky in 1909 , the latest one calling himself "an unbeliever who does not recognize religious mysticism" [Makovsky, 1955, p. 283]. At last, they run counter to the lines from Annensky's poem "Whether a star dims..." (V nebe li merknet zvezda): "I never pray since / I cannot pray, alas" [Four Centuries, 2014, p. 15]. Neither do they coincide with the opinion of B. Paramonov who attributes I. Annensky to "the Western, un-( or anti-, or super-) Christian type of Russian writer" [Paramonov, 2012, p. 28].

Identification of Infinity and a moment, complicated by giving duration to a blink, is an oxymoron from the European point of view. But in the format of Buddhist dogmas, this is a literal statement reflecting the essence of things and the nature of the world order, which does not contain any artistic embellishments. It is exactly what is translated by Annensky. He almost word for word repeats one of the constants of Buddhism, repeatedly voiced in a variety of options.

In the concept of Buddhism, axiological opposites converge at the point of emptiness (shunyata), infinitely small and infinitely great are identical, the opposition between the absolute and the phenomenal, which is usual for the European, does not exist. This basic position of Buddhism is directly formulated in many texts, for example, in the Avatamsaka Sutra (The Flower Ornament Scripture):

"One world system enters all,

And all completely enter one;

Their substances and characteristics remain as before, no different" [Cleary, 1993, p. 215];

"... realizing that past, present, and future are ultimately one instant" [Cleary, 1993, p.1222].

It is important that this very collection of Mahayana sutras is one of the most revered texts of Far Eastern Buddhism. And the sacred action described in the poem "The Buddhist Mass in Paris", involving Annensky, was carried out by
Agvan Dorzhiev, a significant figure in Far Eastern Buddhism [Dugarov, 2016, p. 246]. "Among the colors here, the yellow prevails. Yellow is the color of the Tibetan lamas, known as the Yellow hats (Gelugpa school), to which Dorzhiev belonged" [Ruocco, 2011, p. 279]. That is, Annensky literally heard and deeply experienced the text, which content-based dominants were based on the above citations, reflecting them in one or another interpretation.

It is curious that both the "Buddhist Mass in Paris", which contains the explicit apologetics of Buddhism, or at least a deeply sympathetic attitude towards it, and "Whether a star dims..." which includes the rejection of the church Christianity, contain a single semantic complex with " $\infty$ ": "Infinity becomes a blink / Split by the lightning of a torment"; "While in the air there lived an unpronounced phrase, / Aroused from the soul in a torment of ecstasy" [Ruocco, 2011, p. 283]; "Whether a star dims / Or an earthly torment lasts" [Four Centuries, 2014, p. 15].

Torment accompanies, in equal measure, both the joyful acquisition of a new and parting with the habitual system of world perception. This is also a manifestation of the above-mentioned Buddhist dogma, but already on a different intertextual level:

Sentient beings are oppressed in all states of existence,

Whirled about by habitual delusion, with no one to rescue them [Cleary, 1993, p. 90].

Indulgence is an enemy, a torment and a pain -

It's not the immortal way, but the path of birth and death [Cleary, 1993, p. 362].

The lines of William Blake from "Auguries of Innocence" are another possible source of identification of Infinity and a momentum. Annensky's poem turns out to be identical with Blake's one, conceptually and meaningfully being at the level of the basic statement.

To see a World in a Grain of Sand

And a Heaven in a Wild Flower,

Hold Infinity in the palm of your hand

And Eternity in an hour.

Did Annensky know the work of Blake? None of the indexes to the most nicely commented collections of Annensky's texts contains Blake's name. But a positive answer to this question is not so important. The fact is that researchers and 
interpreters of Blake repeatedly noted the fact that these lines of Blake directly translate important Buddhist maxims and he himself is close to the "Eastern Renaissance" [David, 2003]. Annensky and Blake, separated by time and cultural tradition, both almost unrecognized during life, both versatilely translating their creative potencies, are united by more ancient concepts. Both of them, regardless of the presence or absence of a direct roll call, transmit Buddhist ideas about the world.

The Buddhist blurring of differences or affirming the identity between the small, interval, localized and global, all-encompassing; unlimited is presented in other Annensky's works. The view of the world and its personal perception, refracted in the actions and products of creativity, suggests that only the present time or a segment of space in which a person stays at the moment is relevant for perception. It can be traced in "Sorrow for fleetingness" (Toska mimolotnosti) as well. N.M. Alyokhina reflects closely on poetic semantics, twilight as a special time period with dusk changes of the light, when each thing and every person briefly stops in this transition from one reality to another [Alyokhina, 2013, p. 9]:

I grudge the final seconds of the passing evening In which all that is gone are anguishes and wants, oblivion.

In which all that's to come - dejection and

Here the instant includes everything that has been and will be. This allows saying that the implementation of Buddhist representations is not an exotic episode for the poet, but a stable model that reveals the nature of his worldview.

\section{Conclusion and perspectives}

At the same time, there are some texts in which a profound disclosure of the doctrinal problems of Buddhism is closely linked not only with the personal perception of the world, but also with external representativeness, which establishes parallels between the dogma, the world and the poet, thus joining them in a single substantive complex.

A list of such texts, that are based on the constant of the Buddhist world view, the perception of oneself and the world as indivisible, is long and includes: "Butterfly of Gas" (Babochka gaza), "Alarm clock" (Budilnik), "Drowsiness" (Dremotnost), "Winter train" (Zimniy poyezd), "Impossible" (Nevozmozhno), "My life's burden's for me light and shone" (Nosha zhizni svetla i legka mne...), "Oh No, It is not your Figure" (O net, ne stan), "Oreanda" (Oreanda), "To my companion" (Sputnitse), "The current of mignonette in a dark car" (Struya rezedy v tomnom vagone), "The old barrel organ" (Staraya sharmanka), "The melancholy of the pendulum (Toska mayatnika), "The melancholy of slow drops" (Toska medlennykh kapel), "The melancholy of the time" (Toska mimolotnosti), "Moonlit Night at the End of Winter" (Lunnaya noch na iskhode zimy), "You are again with me" (Ty opyat so mnoy), "A human being" (Chelovek), "I love" (Ya lyublyu), "January fairy tale" (Yanvarskaya skazka).

In these texts the selection of linguistic means is subordinated to the hidden semantics of ambiguity, uncertainty and ambivalence. It is created through combining various tropes, simultaneously updating several meanings of the same word, using syntactic constructions with two different misleads, diffusing the boundaries between synonyms and contextual synonymy, resorting to real or potential enantiosemy and weak semantic positions of the linguistic units. It directly resonates with the general semantics of Buddhist texts and embodies the essential parts of the Buddhist language picture of the world.

A purposeful search for combining the abovelisted linguistic devices and Buddhist semantics in the critical and dramatic texts of I. Annensky in the future will result in expanding thenotion of multidimensionality of his language and the worldview model implemented with its help. In carrying out this analysis, one should avoid unambiguous perception of the language element of the poet.

\section{REFERENCES}

Alyokhina N.M., 2013. Translations of Innokenty Annensky in Context of His Collection "Quiet Songs". Vestnik Tomskogo gosudarstvennogo universiteta [Tomsk State University Journal], no. 367, pp. 7-11.

Annensky I.F., 1979. Books of Reflections. Moscow, Nauka Publ. 691 p.

Bekmetov R.F., 2015. About the "Buddhist View" on Russian Literature. Mediterranean Journal of Social Sciences, vol. 6, no. 3, s. 3, pp. 9-18. DOI: 10.5901/mjss.2015.v6n3s3p9

Borovskaya A.A., 2009. Evolution of Genre Forms in Russian Poetry of the First Third of the Twentieth Century. Astrakhan, Astrahanskiy universitet Publ. 259 p. 


\section{МАТЕРИАЛЫ И СООБЩЕНИЯ}

Catriona H.M., 1985. Innokenty Fedorovich Annensky and the classical ideal: poetry, translations, drama and literary assays. A Thesis Submitted to the Faculty of Medieval and Modern Languages in Partial Fulfilment of the Requirements for the Degree of Doctor of Philosophy. 405 p. URL: https:/ora.ox.ac.uk/ objects/uuid:402cf752-742c-4447-ae0c-ffeace $85 f 95 \mathrm{c}$ (Accessed 17.04.2018).

Cleary T., 1993. The Flower Ornament Scripture. A Translation of the Avatamsaka Sutra. Boston \& London, Shambhala Publications, Inc. 1643 p.

David W., 2003. Brahma in the West: William Blake and the Oriental Renaissance. State University of New York Press. 170 p.

Dugarov B.C., 2016. Who is "a Basaltic Mongol”? (to the History of Writing I. Annensky's Poem "Buddhist Mass in Paris"). Innokenty Annensky (1855-1909): zhizn - tvorchestvo - epokha: Materialy Vserossiiskoy nauchnoprakticheskoy konferentsii (Sankt-Peterburg, 12-14 oktyabrya 2015 goda). Moscow, Azbukovnik Publ., pp. 246-254.

Four Centuries, 2014. Russian Poetry in Translation. Essen, Perelmuter Verlag, no. 8, p. 15.

Makovsky S.K., 1955. Portraits of contemporaries. New York, Izd-vo im. Chehova. 413 p.

McDuffD.W., 1970. Poetry and Aesthetics of Innokenty Annensky. Thesis Presented for the Degree of Doctor of Philosophy of the University of Edinburgh in the Faculty of Arts. Edinburgh. 388 p. URL: https://www.era.lib.ed.ac.uk/handle/ 1842/17392 (Accessed 17 April 2018).
Nalagach N.V., 2003. Christian Motives in I. Annensky's Poem "Quiet Songs". Religioznost v Rossii: sotsialno-gumanitarnye aspekty issledovaniya: materialy Vseros. nauch.-prakt. konf. (Kemerovo, 24-25 noyab. 2003 g.). Kemerovo, Polygraph Publ., pp. 263-268.

Paramonov B., 2012. Russian Literature in the Christian Context // University Libraries. University of Nevada, Las Vegas, pp. 1-29. URL: https:// digitalscholarship.unlv.edu/cgi/viewcontent. cgi ?article $=1019 \&$ context $=$ russian_culture (Accessed 17 April 2018).

Ruocco A.D., 2011. The Buddhist World in Modern Russian Culture (1873-1919): Literature and Visual Arts. URL: http://digitallibrary.usc.edu/ cdm/ref/collection/p15799coll127/id/475242 (Accessed 17 April 2018).

Shuneyko A.A., 2016. Buddhism in the work of Maximilian Voloshin. Trudy Instituta russkogo yazyka im. V.V. Vinogradova. Materialy mezhdunarodnoy nauchnoy konferentsii "Yazyk khudozhestvennoy literatury: traditsionnye $i$ sovremennye metody issledovaniya" pamyati N.A. Kozhevnikovoy (19-21 noyabrya 2016 g.) [Proceedings of the V.V. Vinogradov Russian Language Institute. Materials of International Scientific Conference "The language of Literature: Traditional and Current Research Methods" (November 19-21, 2016)], iss. 10, pp. 344-353.

Varneke B.V., 1910. I.F. Annensky// Zhurnal ministerstva narodnogo prosveshcheniya. Part 26, pp. 37-48. URL: http://annensky.lib.ru/names/varneke/ necrolog.pdf(Accessed 17 April 2018).

\section{Information about the Authors}

Aleksandr A. Shuneyko, Doctor of Sciences (Philology), Professor, Department of Linguistics and Intercultural Communication, Komsomolsk-on-Amur State University, Prosp. Lenina, 27, 681013 Komsomolsk-on-Amur, Russia, a-shuneyko@yandex.ru, https://orcid.org/0000-0001-5467-2214

Olga V. Chibisova, Candidate of Sciences (Cultural Studies), Associate Professor, Department of Linguistics and Intercultural Communication, Komsomolsk-on-Amur State University, Prosp. Lenina, 27, 681013 Komsomolsk-on-Amur, Russia, olgachibisova@yandex.ru, https://orcid.org/0000-0002-2709-2465

\section{Информация об авторах}

Александр Альфредович Шунейко, доктор филологических наук, профессор кафедры лингвистики и межкультурной коммуникации, Комсомольский-на-Амуре государственный университет, просп. Ленина, 27, 681013 г. Комсомольск-на-Амуре, Россия, a-shuneyko@yandex.ru, https://orcid.org/0000-0001-5467-2214

Ольга Владимировна Чибисова, кандидат культурологии, доцент кафедры лингвистики и межкультурной коммуникации, Комсомольский-на-Амуре государственный университет, просп. Ленина, 27, 681013 г. Комсомольск-на-Амуре, Россия, olgachibisova@yandex.ru, https://orcid.org/0000-0002-2709-2465 